\title{
Food Consumption and Assimilation of The Adult Dog Conch Laevistrombus canarium (Linnaeus 1758) at Different Temperatures
}

\author{
Husna, W. N. W. H. ${ }^{1}$, Nurul-Amin, S. M. ${ }^{2}$, Mazlan, A. G. ${ }^{3}$ and Cob, Z. C ${ }^{1 *}$
}

${ }^{1}$ School of Environmental and Natural Resource Science, Faculty of Science and Technology, UniversitiKebangsaan Malaysia, 43600 Bangi, Selangor, Malaysia

${ }^{2}$ Department of Aquaculture, Faculty of Agriculture, Universiti Putra Malaysia, 43400 Serdang, Selangor, Malaysia

${ }^{3}$ Institute of Oceanography and Environment, Universiti Malaysia Terengganu, 21030 Kuala Nerus, Terengganu, Malaysia.

*Corresponding author: zaidicob@gmail.com, nursailormoonsakura@yahoo.com, sm_nurul@upm.edu.my, magfish05@yahoo.com

Received: $1^{\text {st }}$ Nov $2018 \quad$ Accepted: 24 $4^{\text {th }}$ Jul 2019

Published: $28^{\text {th }}$ Aug 2019

DOI: https://doi.org/10.22452/mjs.vol38no2.7

ABSTRACT Laevistrombus canarium (Linnaeus 1758) or the dog conch is a highly important fishery species with great potential for introduction into aquaculture. The present study evaluates food consumption and assimilation by the adult conch at different temperatures (i.e. $22^{\circ} \mathrm{C}, 26^{\circ} \mathrm{C}, 30^{\circ} \mathrm{C}$ and $34^{\circ} \mathrm{C}$ ). The conchs were acclimated for one week in stocking tanks with well-aerated seawater of 30 PSU salinity and at ambient temperature of $26^{\circ} \mathrm{C}$. Prior to experimentation, the gastric emptying level of the conchs were standardized by allowing them to feed till satiation, followed by $24 \mathrm{~h}$ starvation. Ten similar sized aquaria $(20 \times 15 \times 15 \mathrm{~cm})$ were used, each containing one individual conch. Each conch was provided with similar quantity of food $(\sim 102.13 \pm 0.45 \mathrm{mg}$ of sinking pellets $)$ and they were allowed to feed within a $24 \mathrm{~h}$ period. The food consumption rate for adult conchs was significantly different $(\mathrm{p}<0.05)$ between different temperature regimes. Hence, the food absorption efficiency was also affected $(\mathrm{p}<0.05)$, which ranged from $55.21 \%$ to $74.75 \%$. The food energy absorbed showed significant variations between temperatures $(\mathrm{p}<0.05)$. Higher food consumption and assimilation was recorded at $26^{\circ} \mathrm{C}$ followed by $30^{\circ} \mathrm{C}, 34^{\circ} \mathrm{C}$ and $22^{\circ} \mathrm{C}$. Adult $L$. canarium can adapt well in captive conditions by efficiently digesting particularly food pellets. However, more studies are still needed, particularly by adopting longer exposure times as well as higher temperature ranges, in order to better understand the effect of temperatures on the species.

Keywords: Absorption efficiency, energy absorbed, laboratory condition, Merambong shoal, siput gonggong. 


\section{INTRODUCTION}

\section{Dog conch or locally} addressed as 'siput gonggong' is a marine gastropod mollusk species of high economic value (Cob et al., 2008a, Cob et al., 2008b, Cob et al., 2014). It is traditionally collected by the locals for food (Cob et al., 2005; Chuang, 1973) and therefore has great aquaculture potential (Castell, 2003; Cob et al., 2011). Abbott (1960), Amini and Pralampita (1987), Cob et al. (2005) and Erlambang and Siregar (1995) in their studies revealed that this herbivorous (microphagous) mollusk species is generally abundant wherever it occurs and were mostly associated with nearshore sandy mud bottoms areas. Other studies described this species as a tropical marine gastropod closely associated to seagrass bed ecosystems (Cob et al., 2012; Robertson, 1961). Theyare among the dominant herbivorous mollusks in the seagrass bed areas (Cob et al., 2005; 2008c; 2009a; 2009b; 2009c), grazing on delicate filamentous algae or thin layers of organic material from seagrass blades or sand grains (Cob et al., 2014). They were also more active at night than daytime andwere constantly searching for food even when their shells were partially exposed during ebb tide (pers. obs.).

\section{Information regarding} important physiological parameters such as food consumption, food absorption efficiency and food energy conversion are vital and urgently needed if the species is to be introduced into aquaculture. According to Staikou and LazaridouDimitriadou (1989), consumption and assimilation are fundamental stages of energy transport from one trophic level to another, and many terrestrial gastropods being primary consumers, play an important role in the functioning of ecosystems. In addition, energy budgets were determined taking into account acquisition (consumption and absorption) (Navarro et al., 2002). Thus, essential to perform a quantitative study if food ingestion and assimilation in marine snails due to assess their role in ecosystems dynamics (Mason, 1970; Charrier \& Daguzan, 1980; Staikou \& LazaridouDimitriadou, 1989). Nevertheless, preliminary observations on this tropical conch species showed that they readily consumed the introduced food pellet, which allowed for direct measurements of food consumption rate.

Water temperature is one of the major environmental factors that play an important role in determining the scope for growth (SFG) and reproduction of marine organisms (MacDonald \& Thompson, 1986; Bayne \& Hawkins, 1990; Navarro \& Torrijos, 1995). In addition, temperature is also among the most important environment factors crucial in the study of physiology (Resgalla et al., 2007). To date, information regarding the food consumption and assimilation of this species is very 
limited due to lack of studies and knowledge about their ecological importance. The objectives of this study were to determine the food consumption rate and food absorption efficiency of adult $L$. canarium at different temperatures.

\section{MATERIALS AND METHODS}

\section{Sampling and Acclimation}

Conch samples were collected from the Merambong shoal seagrass bed, which is located within the Sungai Pulai estuary, Malaysia $\left(01^{\circ} 19.778^{\prime} \mathrm{N}, 103^{\circ} 35.798^{\prime} \mathrm{E}\right)$ (Figure 1). Merambong shoal has one of the most extensive seagrass beds in Malaysian waters and probably the largest in South East Asia (Bujang et al., 2006). Adult L. canarium were randomly collected during extremely low tide, i.e. between 1.5 to -2.7 MSL tide levels. Adult conch can easily be recognized by their thick and flared outer columella lip (CFMS, 1999; Cob et al., 2009b). Samples were immediately transported to the hatchery facility at Universiti Kebangsaan Malaysia, Bangi, Selangor,

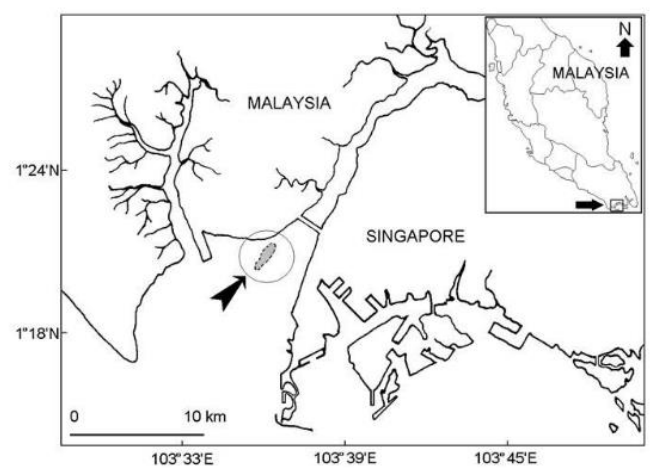

Figure 1. Merambong shoal seagrass bed at the western Johor Straits, Malaysia.

In the hatchery, L. canarium were acclimated in stocking aquaria (length $\mathrm{x}$ width $\mathrm{x}$ height $=1.2 \times 0.5 \mathrm{x}$ $0.58 \mathrm{~m}^{3}, 400 \mathrm{~L}$ ) for one week prior to the experiment. The stocking aquaria were supplied with well-aerated seawater of 30 PSU salinity, and at ambient temperature of $26^{\circ} \mathrm{C}$. Commercial sinking pellets (®HIKARI MARINE MARINE-S-TM, crude protein $\min .48 \%$ ) were offered daily by allowing them to feed to satiation. A known weight of food was supplied ad-libitum to the individual conch. Water quality parameters such as water temperature, $\mathrm{pH}$, dissolved oxygen and salinity were monitored twice daily by using a mercury thermometer, $\mathrm{pH}$ meter, an oxygen meter (YSI Model 59, Yellow Springs Instrument Company OH, USA), and a portable refractometer (ATAGO) respectively. Total ammonia nitrogen $\left(\mathrm{NH}_{3}-\mathrm{N}\right)$ was measured by using the 
salicylate method for seawater (HachTM method 8155). The seawater was changed once every three days to prevent accumulation of metabolic wastes and dead individuals were immediately removed if encountered.

\section{Experimental Set Up}

After acclimation, only healthy conchs were selected, which was based on their activeness. The selected individuals were then measured (total shell length, $\mathrm{mm}$ ) and weighed (total weight, g), and transferred into individual experiment tank of $20 \mathrm{~cm}$ length, $15 \mathrm{~cm}$ width and $15 \mathrm{~cm}$ height. Shell length and total weight for the conchs used in the experiment ranged between 54.00 to $69.00 \mathrm{~mm}$, and 18.00 to $41.00 \mathrm{~g}$, respectively.

A continuous re-circulating system was set up to measure food consumption at each temperature as shown in Figure 2. The conchs were exposed to four different temperatures i.e. $22,26,30$ and $34^{\circ} \mathrm{C}$. The system comprised of ten experimental tanks (T1 to T10) and one control tank (T0), in a temperature-controlled water bath. For the treatments with temperature above ambient the water bath temperature was gradually raised to the target temperature at a rate of $1^{\circ} \mathrm{C}$ day $^{-1}$ by using a thermostat heater (E-JET heater $200 \mathrm{~W}$, Penang, Malaysia) and a heating circulator
(Grant Optima ${ }^{\mathrm{TM}}$ T100, Grant Instruments, Cambridge, England). On the other hand, for the treatment with temperatures below ambient a chiller fitted with a circulator (HS-28 A, 2501200L/H, Guangdong Hailea Grouph Co. Ltd) was used.

The conchs were maintained in their respective experimental temperature for a week. Prior to laboratory experimentation, the hunger levels (gastric emptying levels) of the conchs were standardized by 24 $\mathrm{h}$ starvation after a satiated meal. One animal was placed in each tank (T1 to T10) containing $4 \mathrm{~L}$ of well aerated and filtered seawater $(0.45 \mu \mathrm{m})$. The control tank (T0), which was setup to obtain a correction factor for each treatment, also contained one animal but no food was given. Screens of $1.00 \mathrm{~mm}$ mesh size were fitted at the inflow and outflow of each tank to prevent the food and faeces from escaping. Each tank was provided with similar quantity of food pellets $(102.13 \pm 0.45 \mathrm{mg})$ and the conchs were allowed to feed within a $24 \mathrm{~h}$ period. After the $24 \mathrm{~h}$ feeding period, the seawater flow was stopped and the remaining uneaten pellets and faeces were collected and weighed to the nearest $0.1 \mathrm{mg}$ using an analytical balance (A \& D Company, Limited). Throughout experimentation, all conchs survived under the different temperature treatments. 


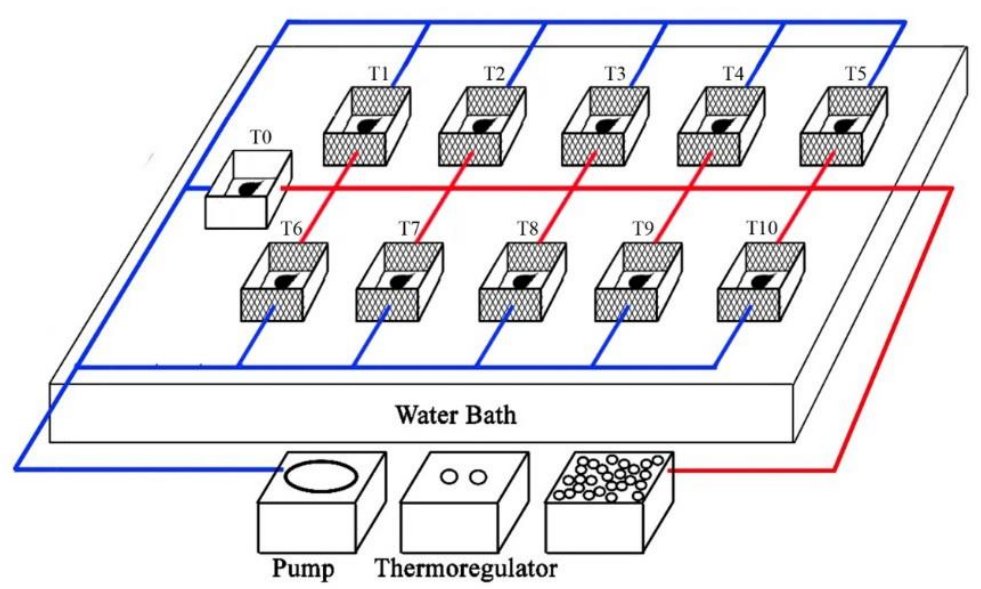

Figure 2. The experimental setup for measurement of food consumption in Laevistrombus canarium. Experimetal tanks (T1 to T10) were provided with sinking pellets, while T0 is a control experiment without food.

\section{Laboratory Analyses} 1995):

The food consumption (FC) was calculated using the equation below (Britz,

$$
F C(m g)=F-R
$$

where, $F C=$ consumption $(\mathrm{mg}), F=$ initial food weight $(\mathrm{mg})$ and $R=$ weight of food remaining $(\mathrm{mg})$ after feeding.

The conch faeces were collected at every four hours till the end of the experiment (the next 24 to $48 \mathrm{~h}$ ), using a Pasteur pipette. The faeces were rinsed with filtered seawater (47 $\mathrm{mm}$ diameter, $0.45 \mu \mathrm{m}$, Whatman GF/F). The remaining salt that adhered to the faeces were washed using distilled water (Smaal \& Widdows, 1994) before oven-dried at $60^{\circ} \mathrm{C}$ for $24 \mathrm{~h}$ to a constant weight. The dried faeces were allowed to cool to room temperature in a desiccator and then re-weighed. Afterwards, they were ashed in a muffle furnace at $550^{\circ} \mathrm{C}$ for $3 \mathrm{~h}$, cooled to room temperature in desiccators and finally re-weighed to estimate the organic content. Food absorption efficiency (AE) was determined by calculating the organic and inorganic (ash) content of the ingested food and faeces. The $\mathrm{AE}$ was calculated following Conover (1966), Bayne and Newell (1983), Kesarcodi-Watson et al. (2001) and Resgalla et al. (2007), using the formula of: 


$$
A E(\%)=(F-E) /[(1-E) F] \times 100
$$

where, $F=$ ash-free dry weight: dry weight ratio of food (g), and $E=$ ash-free dry weight: dry weight ratio of the feaces $(\mathrm{g})$.

The food energy content was determined by using bomb calorimetry (PARR6100, Parr Instrument). The fecal samples were pounded to a fine powder using pestle and mortar. The food energy absorbed were measured following Sobral and Widdows (1997) and Widdows and Johnson (1988) using the formula of:

\section{$E A(J / h)=F C \times A E x E$}

where, $E A=$ food energy absorbed $(\mathrm{J} / \mathrm{h}), F C=$ food consumption rate $\left(\mathrm{g} \mathrm{h}^{-1}\right), A E=$ food absorption efficiency (\%) and $E=$ Energy content of food $\left(\mathrm{J} \mathrm{g}^{-1}\right)$. In this study the conversion factor of $1 \mathrm{~g}$ dry pellet weight $=16469.46 \mathrm{~J}$ was used throughout.

\section{Statistical Analysis}

Prior to any statistical analyses, data distributions were tested for normality and homogeneity of variances. Differences in food consumption, food absorption efficiency and food energy absorbed between the four experimental temperatures were then further analyzed via the univariate method, non-parametric KruskalWallis tests. A Kruskal-Wallis nonparametric analysis was conducted for data that depart from the assumptions of normality and homogeneity of variance. Then, posthoc analyses (Dunn's test for nonparametric) comparison tests were performed to examine the differences among temperature regimes with all parameters at 0.05 probability level. Statistical analyses were conducted using MINITAB® ${ }^{\circledR}$ release 14.1 statistical software.

\section{RESULTS}

Food consumption (FC) by adults $L$. canarium at different temperatures is illustrated in Figure 3. Result indicates that temperature have a highly significant effect on food consumption of adult conchs (Kruskal-Wallis, $\mathrm{p}<0.05$ ) where the mean $\mathrm{FC}$ values at $22^{\circ} \mathrm{C}(2.16 \pm 0.23$ $\mathrm{mg} \mathrm{h}^{-1}$ ) was significantly lower than all the other temperatures tested. The mean $\mathrm{FC}$ values of conchs cultured at $26^{\circ} \mathrm{C}\left(4.04 \pm 0.12 \mathrm{mg} \mathrm{h}^{-1}\right)$ and $30^{\circ} \mathrm{C}$ $\left(4.03 \pm 0.06 \mathrm{mg} \mathrm{h}^{-1}\right)$ did not differ significantly

(Kruskal-Wallis, $\mathrm{p}>0.05$ ), but both were significantly higher (Kruskal-Wallis, $\quad \mathrm{p}<0.05$ ) compared with treatment at $34^{\circ} \mathrm{C}$ $\left(3.42 \pm 0.16 \mathrm{mg} \mathrm{h}^{-1}\right)$. 


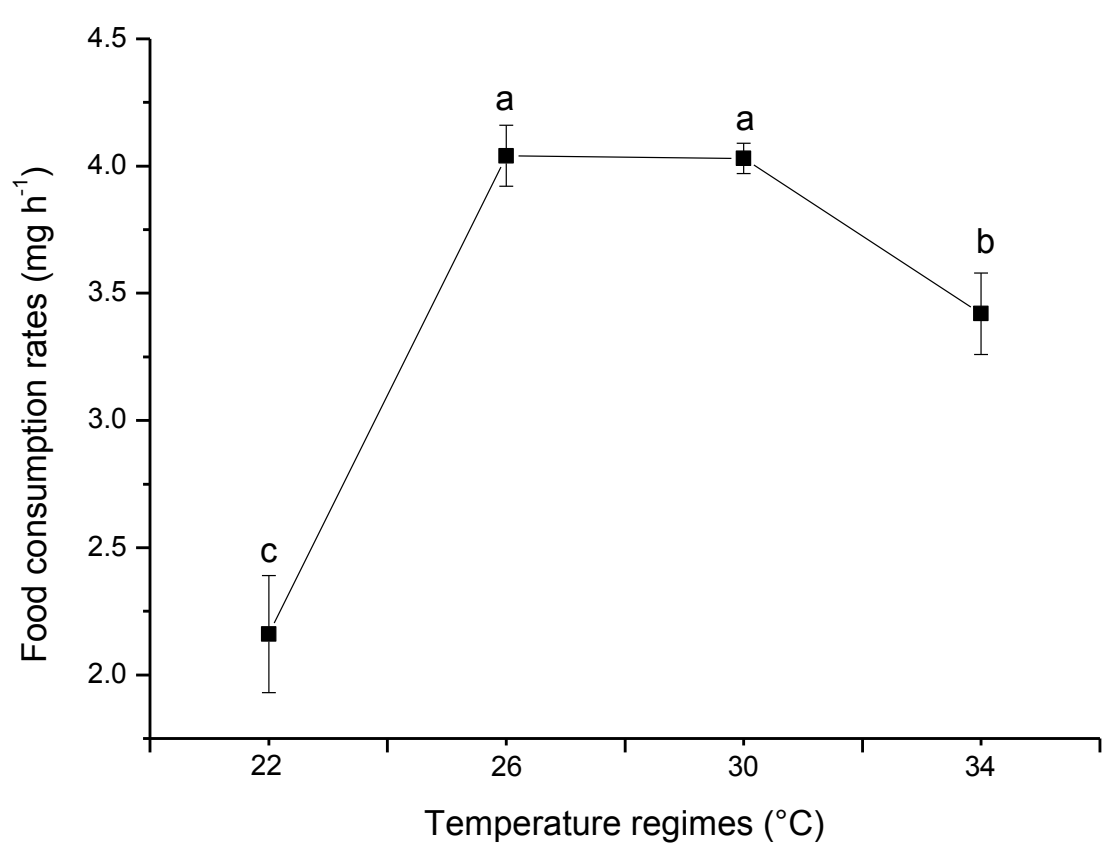

Figure 3. Food consumption rate $\left(\mathrm{mg} \mathrm{h}^{-1}\right)$ by adults Laevistrombus canarium at different temperatures. Values are means \pm standard errors $(\mathrm{N}=10)$. Different letters indicate significant difference between treatments at $\mathrm{p}=0.05$ probability levels.

Food absortion efficiency (AE) for adults $L$. canarium is presented in Figure 4. There was also significant different in adult conch's AE values when cultured in different temperatures (Kruskal-Wallis, $\mathrm{p}<0.05)$. The $\mathrm{AE}$ values recorded at $26^{\circ} \mathrm{C}(74.75 \pm 3.35 \%)$ and $30^{\circ} \mathrm{C}$
$(73.85 \pm 1.50 \%)$ were significantly higher compared with $\mathrm{AE}$ at $22^{\circ} \mathrm{C}$ $(55.21 \pm 4.95 \%)$ and $34^{\circ} \mathrm{C}(55.69 \pm$ $3.18 \%) \quad(p<0.05)$. There was no significant different in $\mathrm{AE}$ values between $26^{\circ} \mathrm{C}$ and $30^{\circ} \mathrm{C}(\mathrm{p}>0.05)$; and between $22^{\circ} \mathrm{C}$ and $34^{\circ} \mathrm{C} \quad(\mathrm{p}>0.05)$ temperature treatments. 


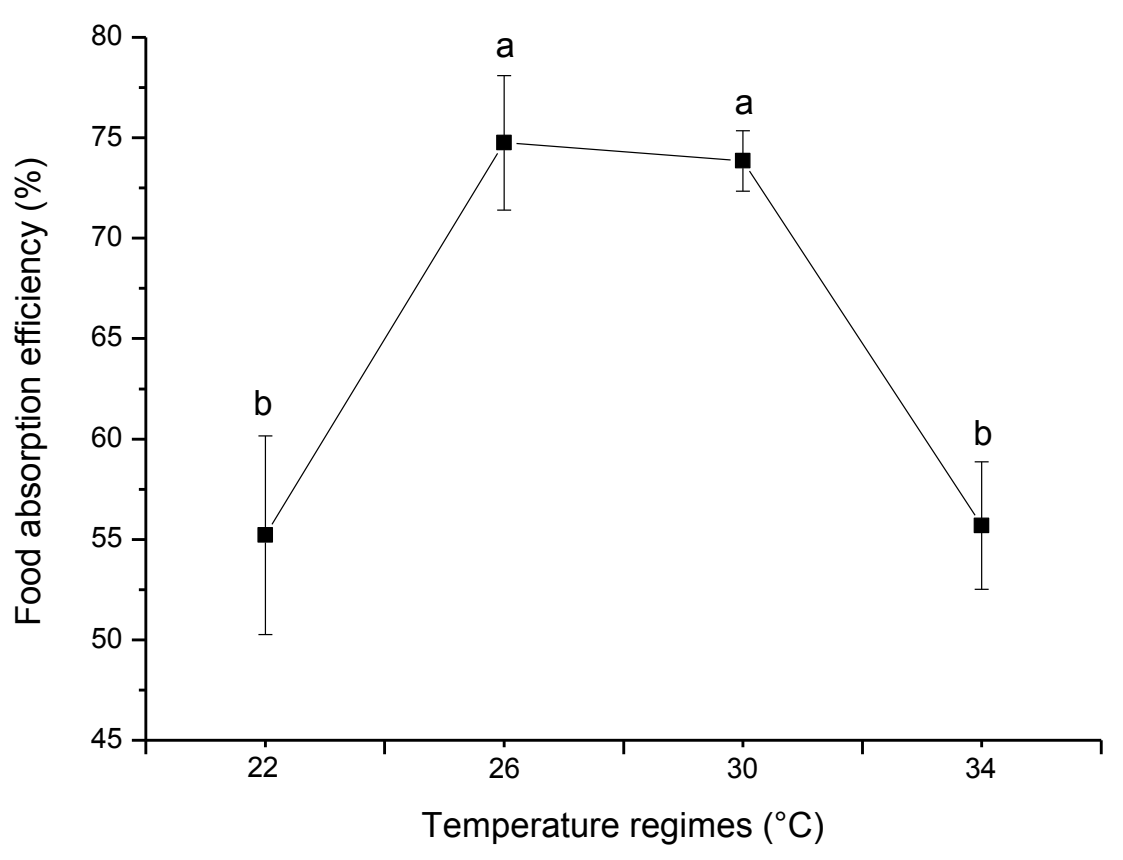

Figure 4. Food absorption efficiency (\%) of adults Laevistrombus canarium at different culture temperatures. Values are means \pm standard errors $(\mathrm{N}=10)$. Different letters indicate significant difference between treatments at $\mathrm{p}=0.05$ probability levels.

Different culture temperatures affected the amount of food energy absorbed (EA) by adult conchs (Kruskal-Wallis, $\quad \mathrm{p}<0.05$ ), as demonstrated by Figure 5 . The mean EA values recorded at $26^{\circ} \mathrm{C}(50.14 \pm$ $\left.3.43 \mathrm{~J} \mathrm{~h}^{-1}\right)$ and $30^{\circ} \mathrm{C}\left(49.09 \pm 1.46 \mathrm{~J} \mathrm{~h}^{-}\right.$ $\left.{ }^{1}\right)$ culture temperatures did not differ significantly $(\mathrm{p}>0.05)$ but were significantly higher than EA at $22^{\circ} \mathrm{C}$ $\left(19.14 \pm 2.41 \mathrm{~J} \mathrm{~h}^{-1}\right)$ and $34^{\circ} \mathrm{C}(31.15 \pm$ $\left.1.99 \mathrm{~J} \mathrm{~h}^{-1}\right)$. There was no significant difference in mean EA values between $22^{\circ} \mathrm{C}$ and $34^{\circ} \mathrm{C}(\mathrm{p}>0.05)$. 


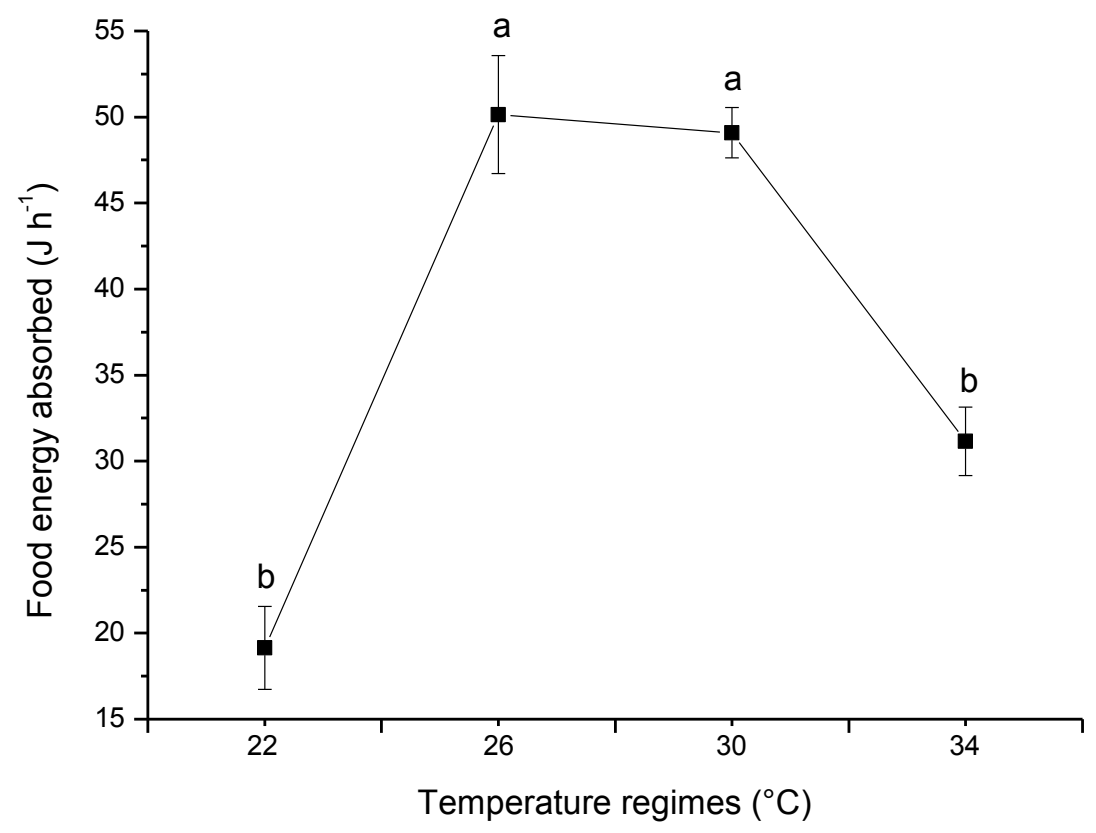

Figure 5. Food energy absorbed $\left(\mathrm{J} \mathrm{h}^{-1}\right)$ by adults Laevistrombus canarium at different temperatures. Values are means \pm standard errors $(\mathrm{N}=10)$. Different letters indicate significant difference between treatments at $\mathrm{p}=0.05$ probability levels.

\section{DISCUSSION}

This study shows that the food consumption (FC values) of adult conch increased with increasing temperature $\left(22\right.$ to $\left.30^{\circ} \mathrm{C}\right)$, but then decreased again at a much high temperature $\left(34^{\circ} \mathrm{C}\right)$. This pattern of fluctuations in FC values against temperatures was similar when compared with previous studies reported by several authors such as Kideys (1997), Navvaro et al. (2002), Resgalla et al. (2007) and Yukihira et al. (2000). The natural habitat where the conch was sampled has a temperature ranged fluctuate between
27 to $30^{\circ} \mathrm{C}$ (Cob, 2008a; Husna et al., 2017). Temperatures lower or higher than these optimum values are expected to affect the conch's overall activity and performance. Husna et al. (2019) reported that the conch can tolerate and become acclimatized to temperatures between 26 to $30^{\circ} \mathrm{C}$. Marine mollusk in general can regulate their activity in response to changes in temperatures through acclimatization, which may increase their capability to survive (Kinne, 1971: Sobral \& Widdows, 1997). This study showed lower activity at lower and higher end of tested temperatures, which indicates that temperatures 
beyond the optimal value can be stressful to the species studied. Previous study on carpet clam (Ruditapes decussatus) by Sobral \& Widdows (1997) also reported a decline in FC values with increasing temperatures, while Walne (1972) revealed that mollusc species are very vulnerable to reduction in temperatures.

In this study, the $\mathrm{AE}$ values for adult conch ranged between $55.21 \%$ to $74.75 \%$, which was relatively low compared with other herbivorous gastropods. Peck et al. (1987) reported $\mathrm{AE}$ values ranged from $78 \%$ to $81 \%$ in abalone Haliotis tuberculate, while Navarro \& Torrijos (1995) reported $\mathrm{AE}$ values from 81 to $95 \%$ for Chilean abalone Concholepas concholepas. On the other hand, Cox and Murray (2006) reported low AE values for the turban snail Lithopoma undosum, which ranged between $34.9 \%$ and $61.2 \%$.

Carnivorous and scavenging gastropods normally show higher values of $\mathrm{AE}$. For example, reported $\mathrm{AE}$ values for Clione limacina ranged from 82 to $98 \%$ (Bayne \& Newell, 1983), and for Thais haemastoma ranged from 81 to $97 \%$ (Bayne \& Newell, 1983). The scavenging gastropod Nassarius festivus that consumed on excise Tapes philippinarum, their reported $\mathrm{AE}$ values ranged from $94 \%$ to as high as 98\% (Cheung et al., 2008). However, some predatory gastropod does show wide range of $\mathrm{AE}$ such as the muricid snail Chorus giganteus with $\mathrm{AE}$ valuesranged from $47 \%$ to $83 \%$ (Navarro et al., 2002); and the trumpet shell Charonia suguenzae with $\mathrm{AE}$ ranged from $45 \%$ to $93.5 \%$ (Doxa et al., 2013).

The relatively lower AE values for $L$. canarium recorded in this study could be related to the low concentration of ash in the food pellets used, compared with other types of food. This was in agreement with Cox \& Murray (2006), who attributed the low AE for L. undosum because they preferentially consume kelps, which has low energy value compared with other macrophytes.

The food energy absorbed (EA) by adult $L$. canarium increased with increasing temperature (22 to $30^{\circ} \mathrm{C}$ ) and then declined when the temperature increased to $34^{\circ} \mathrm{C}$. Results from this study was quite similar with the previous study by Yukihira et al. (2000) on the effect of different temperatures (ranged from $19^{\circ} \mathrm{C}$ to $32^{\circ} \mathrm{C}$ ) on pearl oysters. They found that the upper temperature tested $\left(32{ }^{\circ} \mathrm{C}\right)$, although showed a decline in EA values, was not sufficiently near the lethal temperature of the oysters. Earlier study by Sobral and Widdows (1997) showed that $R$. decussatus, was in stress condition and showed lower EA values at higher temperatures (above $27^{\circ} \mathrm{C}$ ). They concluded that temperature is one of the factors limiting the distribution of marine animal through its effect on their activity level and energy balance. 
For the declined EA values recorded at lower temperature limit, the present finding is quite similar with the previous study by Bashevkin and Pechenik (2015) who demonstrated that the food energy absorbed by Crepidula fornicate was significantly depressed at lower temperatures. On the other hand, Sobral and Widdows (1997) reported that food energy absorbed by $R$. decussatus was higher at low temperature $\left(20^{\circ} \mathrm{C}\right)$ as compared with high temperature $\left(32^{\circ} \mathrm{C}\right)$. This previous finding quite similar with Navarro et al. (2002) who also reported lower food energy absorption at higher temperature but the temperature appears not to influence food absorbed for $C$. giganteus. As indicated by Ansell, (1981) and Bayne \& Newell, (1983), absorption rate is not strongly affected by temperature across normal range.

\section{CONCLUSION}

The optimum temperature for food consumption and assimilation by adult $L$. canarium is between $26^{\circ} \mathrm{C}$ to $30^{\circ} \mathrm{C}$. This likely indicates that $L$. canarium is well adapted to its natural habitat where the temperature ranges roughly between $26^{\circ} \mathrm{C}$ to $30^{\circ} \mathrm{C}$. Thus, any increase or decrease in temperatures from this optimal range most likely will affect their physiological traits. Laevistrombus canarium can adapt well within this optimal temperature range, as showed by their efficiency in consuming and digesting the given food pellet. This study not only determined the optimal temperature range for the best culture practice of this edible marine snail, but more importantly allows us to understand the physiological characteristics of the conch, which is temperature dependent like most other ectothermic organisms. However, more studies are still needed, particularly by adopting longer exposure times as well as higher temperature ranges, in order to better understand the effect of temperatures on the species.

\section{ACKNOWLEDGEMENTS}

This study was funded partly by research grant from the Ministry of Science, Technology and Innovation, Malaysia (MOSTI) through UKM fundamental research grant \#FRGS/2/2014/STWN10/UKM/02/1 and Centre for Research and Innovation Management (CRIM) grant \#AP-2012-013.

\section{REFERENCES}

Abbott R.T. (1960). The genus Strombus in the Indo-Pacific. Indo-Pac. Moll. 1: 33-146.

Amini S. \& Pralampita W.A. (1987). Growth estimates and some biological parameters of gonggong (Strombus canaarium) in Bintan Riau waters. Journal Penelitian 
Perikanan Lauti 41: 29-35.

Ansell A.D. (1981): Experimental studies of a benthic predatorprey relationship. Feeding, growth and egg collar production in long term cultures of the gastropods drill Polinices alderi (Forbes) feeding on the bivalve Tellina tenuis (da Costa). Journal of Experimental Marine Biology and Ecology 56: 1-21.

Bashevkin S.M. \& Pechenik J.A. (2015). The interactive influence of temperature and salinity on larval and juvenile growth in the gastropod Crepidula fornicata (L.). Journal of Experimental Marine Biology and Ecology 470: 78-91. doi:10.1016/j.jembe.2015.05.0 04

Bayne B. L. \& Hawkins A.J.S. (1990). Filter feeding in bivalve molluscs: controls on energy balance. In: Mellinger, J.; Truchot, J. P.; Lahlou, B. ed. Animal nutrition and transport processes. 1. Nutrition in wild and domestic animals. Comparative Physiology 5: 7083.
Bayne B.L \& Newell R.C. (1983). Physiological energetics of marine molluscs. In: Saleuddin, A.S.M., Wilbur, K.M. (Eds.), The Mollusca, Vol. 4, Physiology (Part I). (pp. 407-523), Academic Press, New York.

Britz P.J. (1995). The nutritional requirements of Haliotismidae and development of a practical diet for abalone aquaculture. Rhodes University South Africa. Phd Thesis.

Bujang J.S. \& Zakaria M.H. (2003). The Seagrasses of Malaysia. In: Short F.T. \& Spalding M.D., (Eds.). World Atlas of Seagrasses (pp.152-160), California University Press.

Bujang J.S., Zakaria M.H., \& Aziz, A. (2006). Distribution and significance of seagrass ecosystems in Malaysia. Aquatic Ecosystem Health \& Management 9: 203-214.

Calow P. (1974). Some observations on the locomotory strategies and their metabolic effects in two species of fresh- water gastropods, Ancylus fluviatilis (Mull.) and Planorbis contortus Linn. Oecologia16: 149-161. 
Castell L. (2003). Marine gastropods. In Aquaculture: farming aquatic animals and plants. (pp. 467-487), Fishing New Book.

CFMC. (1999). Queen conch stock assessment and management workshop. Caribbean Fishery Management Council (CFMC), National Marine Fisheries Service, National Oceanic and Atmospheric Administration, Belize City.

Charrier M. \& Daguzan J. (1980). Consommation alimentaire: production et bilan énergétique chez Helix aspersa Müller (Gastéropode pulmoné terrestre). Ann Nutr Aliment 34: 147- 166.

Cheung S.G., Chan H.Y., Liu C.C. \& Shin P.K.S. (2008). Effect of prolonged hypoxia on food consumption, respiration, growth and reproduction in marine scavenging gastropod Nassarius festivus. Marine Pollution Bulletin 57(6-12): 280-286.

Chuang S. H. (1973). Life of the seashore. In S. H. Chuang (Ed.), Animal life and nature in Singapore (pp.150-175), Singapore University Press.
Cob Z.C. (2008a). Biology and ecology of dog conch (Strombus canarium Linnaeus, 1758) (Gastropoda: Strombidae) from Merambong shoal, Johor straits, Malaysia. Ph.D Thesis, University Putra Malaysia.

Cob Z.C., Arshad A., Idris M.H., Bujang J.S. \& Ghaffar M.A. (2008b). Sexual Polymorphism in a Population of Strombus canarium Linnaeus, 1758 (Mollusca: Gastropoda) at Merambong Shoal, Malaysia. Zoological Studies 47(3): 318325 .

Cob Z.C., Arshad A., Bujang J.S. \& Ghaffar M.A. (2009a). Age, growth, mortality and population structure of Strombus canarium (Gastropoda: Strombidae): variations in male and female sub-populations. Journal of Applied Sciences 9(18): 32873297.

Cob Z.C., Arshad, A., Bujang J.S. \& Ghaffar M.A. (2009b). Species description and distribution of Strombus

(Mollusca: Strombidae) in Johor Straits and its surrounding areas. Sains Malaysiana 38(1): 3946. 
Cob Z.C., Arshad A., Bujang J.S. \& Ghaffar M.A. (2011). Description and evaluation of imposex in Strombus canarium Linnaeus, 1758 (Gastropoda, Strombidae): a potential bioindicator of tributyltin pollution. Environ. Monit. Assess. 178: 393-400.

Cob Z.C., Arshad A., Bujang J.S., Amin S.M.N. \& Ghaffar M.A. (2008c). Growth, Mortality, Recruitment and Yield-perrecruit of Strombus canarium Linnaeus, 1758 (Megastropoda: Strombidae) from the West Johor Straits, Malaysia. Research Journal of Fisheries and Hydrobiology 3(2): 71-77.

Cob Z.C., Arshad A., Bujang J.S., Bakar Y., Simon K.D. \& Mazlan A.G. (2012). Habitat preference and usage of Strombus canarium Linnaeus, 1758 (Gastropoda: Strombidae) in Malaysian seagrass beds. Italian Journal of Zoology 79(3): 459- 467.

Cob Z.C., Arshad A., Bujang J.S., Husna W.N.W.H. \& Ghaffar, M.A. (2014). Feeding behaviour and stomach content analysis of Laevistrombus canarium (Linnaeus, 1758) from Merambong shoal, Johor. Malayan Nature Journal 66(1 and 2): 159-170.
Cob Z.C., Arshad A., Ghaffar M.A., Bujang J.S. \& Muda W.L.W. (2009c). Development and Growth of Larvae of the Dog Conch, Strombus canarium (Mollusca: Gastropoda), in the Laboratory. Zoological Studies 48(1): 1-11.

Cob Z.C., Japar S.B., Mazlan A.G. \& Arshad A. (2005). Diversity and population structure characteristics of Strombus (Mesogastropod, Strombidae) in Johor Straits. In: Proceeding of the 2nd Regional Symposium on Natural Environment and Natural Resources. (pp.2:198-205), Universiti Kebangsaan Malaysia, Malaysia.

Conover R.J. (1966). Assimilation of organic matter by zooplankton. Limnol. Oceanogr. 11: 338345.

Cox T.E. \& Murray Æ.S.N. (2006). Feeding preferences and the relationships between food choice and assimilation efficiency in the herbivorous marine snail Lithopoma undosum (Turbinidae). Marine Biology 148: 1295-1306. 
Doxa C.K., Divanach P. \& Kentouri M. (2013). Consumption rates and digestibility of four food items by the marine gastropod Charonia seguenzae (Aradas \& amp; Benoit, 1870). Journal of Experimental Marine Biology and Ecology 446: 1016.

Egonmwan R. I. (2007). Food utilisation in a laboratory colony of the Giant African Land Snail (Swainson) (Pulmonata: Achatinidae). Turk J. Zool. 31: 265-270.

Erlambang T. \& Siregar Y.I. (1995). Ecological aspects and marketing of dog conch Strombus canarium Linne, 1758 at Bintan Island, Sumatra, Indonesia. Special Publication Phuket. Marine Biological Center 15: 129-131.

Gosselin L.A. \& Qian P.Y. (1997). Juvenile mortality in benthic marine invertebrates. Mar. Ecol. Prog. Ser. 146:265-282.

Hunt H.L. \& Scheibling R.E. (1997). Role ofearly post-settlement mortality in recruitment of benthic marine invertebrates. Mar. Ecol. Prog. Ser.155: 269-301
Husna W.N.W.H., Mazlan A.G. \& Cob Z.C. (2017). Ontogenetic changes in feeding and food preferences of the dog conch Laevistrombus canarium Linnaeus 1758 (Mollusca: Gastropoda) from Merambong shoal, Malaysia. Chinese Journal of Oceanology and Limnology 35(5): 1230-1238.

Husna W.N.W.H., Nurul-Amin S.M., Mazlan A.G. \& Cob Z.C (2019) Effects of Temperature on Food Consumption of Juveniles Dog Conch, Laevistrombus canarium (Linnaeus 1758) in Llaboratory Condition. Journal of Sustainability Science and Management 14(1): 1-10.

Kideys A.E. (1997) Physiological energetics of Buccinum undatum L. (Gastropoda) off Douglas, Isle of Man (the Irish Sea) Tr. J. of Zoology 22: 4961.

Kinne, O. (1971). Salinity: Animals. Invertebrates. In: Kinne O (ed) Marine ecology Vol 1. Part 2. (pp.821-996), Wiley, London. 
Iglesias J.I.P., Urrutia M.B., Navarro E. \& Ibarrola, L. (1998). Measuring feeding and absorption in suspension feeding bivalves: an appraisal of the biodeposition method. $J$. Exp.Mar. Biol. Ecol. 219: 7186.

Kesarcodi-Watson A., Lucas J.S. \& Klumpp D.W. (2001). Comparative feeding and physiological energetics of diploid and triploid Sydney rock oysters, Saccostrea commercialis I. Effects of oyster size. Aquaculture 203: 177-193.

MacDonald B.A. \& Thompson R.J. (1986). Influence of temperature and food availability on the ecological energetics of the giant scallop Placopecten magellanicus. III. Physiological ecology, the gametogenic cycle and scope for growth. Mar. Biol. 93: 3748.

Mason C.F. (1970). Food, feeding rates and assimilation in woodland snails. Oecologia 4: 358-373.
Navarro J.M., Leiva G.E., Gallardo C.S. \& Varela, C. (2002). Influence of diet and temperature on physiological energetic of Chorus giganteus (Gastropoda: Muricidae) during reproductive conditioning. New Zealand. Journal of Marine and Freshwater Research 36: 321332.

Navarro J.M. \& Torrijos R.A. (1995). Fisiología energetica de Concholepas concholepas (Bruguiere, 1789) (Gastropoda: Muriciae) en la bahía de Yaldad, sur de Chile. Revista Chilena de Historia Natural 68: 61-77.

Navarro J.J.M., Urrutia G.G.X. \& Carrasco C. (2006). Scope for growth versus actual growth in the juvenile predatory gastropod Chorus giganteus. Journal of the Marine Biological Association of the UK 86(06): 1423-1428.

Peck L.S., Culley M.B. \& Helm M.M. (1987). A laboratory energy budget for the ormer Haliotis tuberculata L. J. Exp. Mar. Biol. Ecol. 150: 103-123. 
Resgalla C., Elisângela J., Brasil D.S. \& Salomão L.C. (2007). The effect of temperature and salinity on the physiological rates of the mussel Perna perna (Linnaeus 1758). Brazilian Archives of Biology and Technology50(3): 543556.

Robertson R. (1961). The feeding of Strombus and related herbivorous marine gastropod. Natulae Naturae of the Academy of Natural Sciences of Philadelphia 343: 1-9.

Smaal AS. \& Widdows, J. (1994). The scope for growth of bivalves as an integrated response parameter in biological monitoring. In: Kramer, K. J. M. (Ed.), Biomonitoring of Coastal Waters and Estuaries. (pp. 247-262), CRC Press, Boca Raton.

Widdows J. \& Johnson D. (1988). Physiological energetics of Mytilus edulis: Scope for Growth. Marine Ecology Progress Series 46: 113-121.
Sobral P. \& Widdows J. (1997). Effects of elevated temperatures on the scope for growth and resistance to air exposure of the clam Ruditapes decussatus (L.), from southern Portugal. Scientia Marina 61(1): 163171.

Staikou A. \& Lazaridou-Dimitriadou M. (1989). Feeding experiments on and energy flux in a natural population of the edible snail Helix lucorum L. (Gastropoda: Pulmonata: Stylommatophora) in Greece. Malacologia 31: 217-227.

Walne P.R. (1972). The influence of current speed, body size and water temperature on the filtration rates of five species of bivalves. J. Mar. Biol. Ass. $U K$

52:

345-374

Yukihira H., Lucas J.S. \& Klumpp D.W. (2000). Comparative effects of temperature on suspension feeding and energy budgets of the pearl oysters Pinctada margaritifera and $P$. maxima. Mar. Ecol. Prog. Ser. 195: 179-188. 